\title{
Przyczynki do flory Tatrzańskiego Parku Narodowego
}

\author{
Antoni Zięba, SŁawomir Wróbel, †PaweŁ Kauzal, Anna Delimat, \\ Anna Maria Ociepa, Maciej KozaK, Katarzyna KozŁowska-KozaK, \\ Patryk Czortek, Jakub Baran, Grzegorz Bryniarski, Wojciech Gąsienica-Roj, \\ Wojciech Tylka, Filip Zięba, Pawę Nejfeld, Monika Kawulak i Marcin Widlak
}

\begin{abstract}
Zięba, A., Wróbel, S., †Kauzal, P., Delimat A., Ociepa A. M., Kozak M., KozŁowskaKozak K., Czortek P., Baran J., Bryniarski, G., Gąsienica-Roj, W., Tylka, W., Zięba F., Nejfeld P., Kawulak M. and Widlak M. 2020. Notes on the flora of Tatra National Park (Poland). Fragmenta Floristica et Geobotanica Polonica 27(2): 379-394. Kraków. e-ISSN 2449-8890, ISSN 1640-629X.
\end{abstract}

ABSTRACT: The paper presents new localities of rare, threatened and newly discovered vascular plant species of Tatra National Park (S Poland). Data were collected during several field studies carried out in 2010-2019. We describe 131 localities of 42 taxa, including basic topographic, site and population data.

KEY WORDS: endemic plants, Natura 2000 species, new localities, Tatra Mountains, threatened species

A. Zięba (autor korespondencyjny), S. Wróbel, P. Kauzal, G. Bryniarski, W. Gqusienica-Roj, W. Tylka, F. Zięba, Tatrzański Park Narodowy, ul. Kuźnice 1, 34-500 Zakopane, Polska; e-mail: azieba@tpn.pl

A. Delimat, e-mail: delian@poczta.onet.pl

A. M. Ociepa, FUP Kościelisko, skrytka nr 17, 34-511 Kościelisko, Polska; e-mail: amociepa@ interia.pl

M. Kozak, e-mail: maciejkozak1@tlen.pl

K. Kozłowska-Kozak, e-mail: katarzyna.kozlowska2@gmail.com

P. Czortek, Białowieska Stacja Geobotaniczna, Wydziat Biologii, Uniwersytet Warszawski, ul. Sportowa 19, 17-230 Białowieża, Polska; e-mail: patrykczortek@biol.uw.edu.pl

J. Baran, Ojcowski Park Narodowy, Ojców 9, 32-045 Sułoszowa, Polska

P. Nejfeld, Pracownia Ekspertyz Środowiskowych DENDRUS, ul. Batorego 27, 34-300 Żywiec, Polska; e-mail: pawelnejfeld@interia.pl

M. Kawulak, monikakawulak@wp.pl

M. Widlak, Lasy Państwowe, Nadleśnictwo Gorlice, Zagórzany 343, 38-333 Zagórzany, Polska; e-mail: marcin.widlak@krakow.lasy.gov.pl

\section{WSTĘP}

Tatry są jednym z najcenniejszych florystycznie rejonów w Europie Środkowej. Dotychczas podano z tego obszaru (ok. $785 \mathrm{~km}^{2}$ ) występowanie ponad 1400 gatunków roślin naczyniowych, z czego po polskiej stronie ok. 1100 (MireK \& PięKOŚ-MirkowA 1996, 2005; 
ŠoltéSOvÁ i in. 2010). Stanowi to ponad 40\% flory naszego kraju. Istotną częścią z tej puli są gatunki górskie, których na terenie Tatrzańskiego Parku Narodowego (TPN) stwierdzono ok. 400, w tym ok. 200 takich, które mają tutaj swoje jedyne miejsce występowania w Polsce (MireK \& PiĘKoś-Mirkowa 1996). Tatry są również najdalej na północ wysuniętym centrum endemizmu w Europie z 90 taksonami endemicznymi (MireK \& PięKoś-Mirkowa 2005, 2010; Mráz i in. 2016).

Historia poznania flory Tatr sięga XVIII w. (RADwAŃSKA-PARYSKA 1991). Szczególnie ważne badania nad szatą roślinną tego pasma górskiego były prowadzone pod koniec XIX w., kiedy to rozpoczęto szczegółowo opisywać florę Tatr (KotUla 1889-1890; BERDAU 1890; SAGORSKI \& SCHNEIDER 1891) oraz w okresie dwudziestolecia międzywojennego, gdy dokonano jednych z pierwszych w Polsce i na świecie badań fitosocjologicznych, opisując tatrzańskie zbiorowiska roślinne (SZAFER i in. 1923; PAwŁowski i in. 1928). Wiek XX i początek XXI przyniósł dalszy rozwój wiedzy na temat szaty roślinnej Tatr. Skupiano się w tym czasie zarówno nad lepszym poznaniem zbiorowisk roślinnych, rozmieszczeniem najcenniejszych gatunków roślin i ich ekologią, jak również dokonywano syntezy dotychczasowego stanu wiedzy (PAWŁowsKi 1956; MYCZKOWSKI \& LESIŃSKI 1974; RADWAŃSKA-Paryska 1975; Pięroś-Mirkowa 1982; Balcerkiewicz 1984; Mirek \& Piękoś-Mirkowa 1996, 2005, 2010; ZwIJACZ-Kozica 1997). Co ciekawe, pomimo tak długiej i szczegółowej historii badań nad tatrzańską florą, niemal każdy rok w ostatnich kilkunastu latach przynosił nowe, interesujące odkrycia dotyczące cennych gatunków roślin (Delimat \& BORUCKI 2009; KRUK 2012; BinkieWiCZ 2014; ZięBA 2014; KruK i in. 2015; MireK i in. 2015; CZORTEK i in. 2017; ZięBa \& Baran 2017; Wróbel \& Figura 2018; Wróbel \& Wróbel 2018; ZiĘBA 2018; ZwIJACZ-KoZICA \& ZwIJACZ-KoZICA 2018).

Celem pracy jest prezentacja nowych, dotychczas niepublikowanych stanowisk rzadkich gatunków roślin w TPN. W szczególności uwzględniono gatunki ujęte w Polskiej czerwonej księdze roślin (KAźMIERCZAKOwa i in. 2014), Czerwonej księdze Karpat polskich (Mirek \& Pię́oś-Mirkowa 2008), Polskiej czerwonej liście paprotników i roślin kwiatowych (Kaźmierczakowa i in. 2016) oraz nowe dla Tatrzańskiego Parku Narodowego. Za taksony nowe dla TPN przyjęto wszystkie te, które nie zostały wymienione w Operacie ochrony roślin naczyniowych (MIREK i in. 2013, mat. niepubl.), sporządzonym na potrzeby przygotowania projektu Planu Ochrony TPN.

\section{UWAGI METODYCZNE}

W latach 2010-2019 przeprowadzono na terenie Tatrzańskiego Parku Narodowego szereg badań, w trakcie których zgromadzono wiele dat florystycznych (BODZIARCZYK i in. 2019; SZWAGRZYK i in. 2019). Precyzyjne lokalizacje (współrzędne geograficzne) stanowisk zbierano za pomocą odbiornika Garmin GPSmap 62s, które następnie zgromadzono w wewnętrznej geobazie Tatrzańskiego Parku Narodowego.

W niniejszej pracy prezentujemy lokalizacje, podstawowe parametry siedliskowe i populacyjne stanowisk wybranych gatunków roślin naczyniowych. Wykaz taksonów przygotowano według schematu: nazwa gatunkowa, kategoria zagrożenia ${ }^{1}$ według Polskiej czerwonej księgi roślin, kategoria zagrożenia

1 CR - krytycznie zagrożone (critical), EN - zagrożone (endangered), VU - narażone (vulnerable), LR - niskiego ryzyka (lower risk), NT - bliskie zagrożenia (near threatened), DD - stopień zagrożenia trudny do określenia z braku danych (data deficient). 
(w nawiasie) według Czerwonej księgi Karpat polskich, kategoria zagrożenia (w nawiasie kwadratowym) według Polskiej czerwonej listy paprotników i roślin kwiatowych, rodzaj ochrony, kod Natura 2000 według Dyrektywy Siedliskowej UE, informacja czy gatunek jest endemitem, nazwa topograficzna stanowiska, wysokość [m n.p.m.], wystawa, opis stanowiska z uwzględnieniem siedliska, podstawowe parametry populacyjne (liczba pędów, powierzchnia płatu, itp.), dodatkowe informacje, data obserwacji, inicjały autora/ autorów ${ }^{2}$ obserwacji, z zastrzeżeniem, że nie wszystkie z powyższych informacji znajdują się przy każdym taksonie. W przypadku nowych gatunków dla flory TPN, nazwa tych taksonów poprzedzona jest znakiem!, a opis rozpoczyna krótka informacja na temat gatunku, ze szczególnym uwzględnieniem stanowisk położonych w sąsiedztwie Tatr. Ponadto w przypadku gatunków nieuwzględnionych w Polskiej czerwonej księgi roślin, a rzadkich na terenie TPN (tj. Berberis vulgaris, Campanula glomerata, Cephalanthera longifolia, Epipactis palustris, Salvia verticillata, Vincetoxicum hirundinaria) opis rozpoczyna krótka informacja na temat dotychczasowych stanowisk w Tatrach. Nazwy taksonów roślin naczyniowych przyjęto za opracowaniem MiRKA i in. (2002).

\section{WYKAZ GATUNKÓW}

Aconitum firmum subsp. moravicum - VU, (VU), [VU], ochrona ścisła, kod Natura 2000: 4109; 1) Polana Waksmundzka, ok. 1370, w pobliżu cieku wodnego przepływającego przez polanę, osiem pędów kwiatostanowych, 26.08.2015 r., SW; 2) Dolina Mułowa, 1720, w płacie ziołorośli na dnie dolnego, płaskiego piętra doliny, 70 pędów kwiatostanowych, 09.08.2017 r., SW; 3) stok opadający z Machajówki do Doliny Mułowej, 1840, wystawa: W, w płacie ziołorośli zajmującym niewielkie zagłębienie terenu, sześć pędów kwiatostanowych, 09.08.2017 r., SW; 4) Wyżnia Dudowa Rówień, 1180, wystawa: SW, na polanie reglowej, sześć pędów kwiatostanowych, 13.07.2018 r., SW.

! Arctium nemorosum - [DD]; dotychczas niepodawany z polskiego Podtatrza. Najbliższe stanowiska znajdują się w Pieninach (KaźmIERCZAKOwa \& PERZANOwSKa 2001; ZaJĄC \& ZAJĄC 2001). Dolina Łężna, ok. 1035, wystawa: SE, niewielki płat jaworzyny na stromym stoku, przylegający do powierzchni powiatrołomowej, nieliczny - kilka osobników, 29.08.2018 r., PN.

Artemisia eriantha - VU, (LR), [VU], kod Natura 2000: 1763; 1) Wołowiec, ok. 1720, wystawa: N, w szczelinach skał metamorficznych, pięć kwitnących kęp, 02.08.2017 r., SW; 2) Starorobociański Wierch, 1855-1985, wystawa: N, w szczelinach skał metamorficznych, 42 kwitnące kępy, 28.06.2017 r., 04.07.2017 r., SW; 3) powyżej przełęczy Pyszniańskiej, 1800, wystawa: N, w szczelinach skał metamorficznych, jedna kwitnąca kępa, 20.06.2017 r., SW; 4) Wielki Piarg, 1517, wystawa: N, piarg granitowy, dwa osobniki wegetatywne, 20.08.2018 r., SW, AZ. Artemisia eriantha z piargów nad Morskim Okiem (ok. 1460) była podawana już przez PAwŁowSKIEGO i in. (1928) oraz KosIŃsKIEGO (1999), jednak od czasu tej ostatniej obserwacji, stanowisko to nigdy nie zostało potwierdzone. Prawdopodobnie stanowiska gatunku na Wielkim Piargu mają charakter efemeryczny - przy korzystnych warunkach roślina ta pojawia się na piargu (osobniki stanowiące źródło diaspor rosną w bezpośrednim sąsiedztwie w ścianach masywu Mięguszowieckich Szczytów), jednakże podczas dużych lawin kamiennych, obrywów skalnych, wezbrań wody w żlebach mogą one być okresowo niszczone; 5) Żleb spod Hińczowej Przełęczy, ok. 2250, wystawa: N, wilgotne szczeliny skalne i piargi granitowo-mylonitowe u wylotu żlebu do Wielkiej Galerii Cubryńskiej, jeden osobnik wegetatywny, 12.09.2019 r., AZ.

Astragalus australis - VU, (VU), [VU]; 1) Kamienne Tomanowe, 1425-1587, wystawa: E, w murawie nawapiennej, kilkanaście kwitnących kęp na powierzchni kilkudziesięciu m², 28.07.2012 r., AD; 2) Mała Świstówka, 1544, wystawa: E, w murawie nawapiennej, kilka kwitnących osobników; z Małej Świstówki były dotychczas znane stanowiska z wysokości 1320-1370 (PAwŁowsKI 1925, 1956; PAWŁowSKI \& STECKI 1927), 07.08.2017 r., AD; 3) Dziurawe - pomiędzy Małą, a Wielką Świstówką, 1557, wystawa: NW, w murawie nawapiennej, kilka kwitnących kęp, 21.08.2018 r., AD; 4) południowozachodni stok

\footnotetext{
2 W przypadku osób o takich samych inicjałach zastosowano następujący zapis: Monika Kawulak - MKa, Maciej Kozak - MKo.
} 
Kominiarskiego Wierchu, 1529, wystawa: SW, w murawie nawapiennej, kilka kęp, stanowisko być może tożsame z podanym przez PAWŁOWSKIEGO (1956), 01.09.2018 r., AMO.

Astragalus frigidus - VU, (VU), [VU]; 1) zbocze Doliny Litworowej - powyżej Litworowego Kotła w kierunku grzbietu pomiędzy Doliną Litworową a Doliną Mułową, wystawa: SE, 1835, w piargu i murawie nawapiennej, kilkanaście kwitnących kęp, 13.08.2013 r., AD; 2) Kopa Kondracka - stok opadający do Doliny Małej Łąki, 1890, wystawa: N, w murawie nawapiennej, kilka małych kwitnących kęp na powierzchni ok. $50 \mathrm{~m}^{2}$, 11.07.2015 r., SW; 3) Piekło w Dolinie Kondratowej, 1595, wystawa: NE, w murawie nawapiennej, kilka małych kwitnących kęp na powierzchni ok. $10 \mathrm{~m}^{2}$, 23.07.2016 r., SW; 4) na południowy zachód od jaskini Studnia w Małej Świstówce, 1552, wystawa: NE, w murawie nawapiennej, kilka kwitnących osobników; z Małej Świstówki były dotychczas znane stanowiska z wysokości 1360-1400 (Pį̨KOŚ-MiRKowa 1982; ŁoBARZEWSKA 1984), 21.08.2018 r., AD.

Berberis vulgaris - gatunek znany dotychczas w TPN z dwóch stanowisk: na Jastrzębiej Turni (ZwoLIŃSKA 1957; ZWIJACZ-KozICA 1997) i Łysej Skałce (ŁYSEK 1974). 1) Wielki Kopieniec, 1150, wystawa: $\mathrm{W}$, w murawie nawapiennej opanowanej przez jałowiec pospolity, trzy krzewy z tego dwa owocujące, 11.10.2012 r., SW; 2) na stoku Stołów opadającym do Doliny Kościeliskiej, 1170, wystawa: SE, w szczelinie wapiennej skały, jeden stary, owocujący krzew, 20.06.2018 r., SW.

! Brachypodium sylvaticum - roślina pospolita w Polsce, zwłaszcza w lasach z klasy Querco-Fagetea, jednakże na polskim Podtatrzu bardzo rzadka. Znana zaledwie z trzech stanowisk w Rowie Podtatrzańskim: Roztoki, Bilinówka, nad Białką w okolicy Bukowiny Tatrzańskiej (MireK 2016). 1) Dolina Kościeliska - Pośrednia Kopka, 998, wystawa: E, powierzchnia powiatrołomowa z częściowo uprzątniętymi drzewami, obsadzona bukiem (Fagus sylvatica) i jaworem (Acer pseudoplatanus), osiagającymi kilka metrów wysokości, nieliczny, 15.07.2018 r., AD; 2) Dolina Kościeliska - ponad Bramą Kantaka (Kopki Kościeliskie), 993, wystawa: N, powierzchnia powiatrołomowa z częściowo uprzątniętymi drzewami, kilka kęp, 15.07.2018 r., AD; 3) Dolina ku Dziurze, 900, wystawa: NE, żyzna buczyna karpacka, wzdłuż krawędzi szlaku turystycznego w pobliżu wylotu doliny, płat o powierzchni ok. $4,5 \mathrm{~m}^{2} \mathrm{z}$ licznymi okazami generatywnymi, 15.10.2019 r., PK.

Callianthemum coriandrifolium - VU, (LR), [VU]; 1) Dolina Pięciu Stawów Polskich - przy wypływie potoku z Wielkiego Stawu, 1664, wystawa: NE, murawa subalpejska, przy potoku, ok. $16 \mathrm{~m}$ od szlaku, siedem osobników generatywnych, jeden osobnik wegetatywny, stanowisko zlokalizowane jest blisko szlaku. Zaobserwowano ślady wydeptywania terenu przez turystów, w związku z czym proponuje się zabezpieczenie tego obszaru np. poprzez fladrowanie. 30.05.2018 r., AZ; 2) Wielki Staw Polski, 1669, wystawa: NW, wilgotne traworośla z udziałem m.in. Carex sempervirens, Swertia perennis, Viola biflora na stromym, południowowschodnim brzegu stawu, pięć osobników generatywnych i kilkanaście wegetatywnych, 08.06.2018 r., PK.

Campanula glomerata - Gatunek znany dotychczas w TPN z trzech stanowisk: Łysa Skałka (PAWŁowski $\mathrm{i}$ in. 1928), Dolina Jaworzynka (MireK \& PięKoś-Mirkowa 1985), Dolina Białego (Kotula 1889-90). Wrótka w masywie Giewontu, 1510-1600, wystawa: S, murawa nawapienna, kilkaset kwitnących roślin, 05.07.2018 r., SW.

Campanula serrata - VU, (VU), [VU], ochrona ścisła, kod Natura 2000: 4070*, endemit karpacki; 1) Tomanowy Grzbiet ponad Kamiennym Tomanowym, 1763, wystawa: SW, w płacie traworośli, kilka metrów od zielonego szlaku z Chudej Przełączki do Doliny Tomanowej, kilkanaście kwitnących pędów na powierzchni kilku m², 07.09.2011 r., AD; 2) Smreczyński Wierch, 1900, wystawa: NW, w płacie traworośli z Calamagrostis villosa z udziałem Vaccinium myrtillus, w pobliżu płaty muraw wysokogórskich z Juncus trifidus, kilkadziesiąt $\mathrm{w}$ większości kwitnących pędów na powierzchni kilku $\mathrm{m}^{2}$, 12.08.2012 r., MKo, KKK; 3) Przednie Kamienne, 1620-1650, wystawa: SW, mozaika płatów muraw, traworośli i borówczysk wśród luźnych zarośli kosówki, łącznie w dwóch miejscach, ok. 100 pędów generatywnych, rosnących na powierzchni kilkunastu $\mathrm{m}^{2}$, 28.07.2015 r., AD, 28.07.2019 r., MKo, KKK; 4) Wielka Polana Ornaczańska, 1129, wystawa: N, w płacie traworośli, kilkanaście osobników, przeważnie kwitnących na powierzchni kilku m², 30.07 .2015 r., AD; 5) Kopa Kondracka, 1850, wystawa: NE, 28 pędów generatywnych na powierzchni $5 \mathrm{~m}^{2}$, 07.08.2018 r., SW; 6) Dolina Sucha Kondracka, 1640-1650, wystawa: NE, traworośla z Calamagrostis villosa, 154 pędy generatywne w trzech skupieniach 
na powierzchni ok. 0,1 ha, 10.08.2018 r., SW; 7) Pośredni Goryczkowy Wierch, 1730, wystawa: NE, traworośla z Calamagrostis villosa, 80 pędów generatywnych na powierzchni ok. $25 \mathrm{~m}^{2}, 10.08 .2018$ r., SW; 8) Upłaziańska Kopa, 1790, wystawa: NE, murawa subalpejska poniżej kępy kosówki, miejscami poprzetykana borówczyskami, sześć pędów generatywnych, w pobliżu bardzo licznie występuje Campanula polymorpha, 12.08.2019 r., AZ.

Carex capillaris - [VU]; 1) Łysanki - Kohut ponad Małym Żlebkiem, 1233, wystawa: NE, luka w młodym lesie świerkowym, porastającym stary wiatrołom (liczne rozkładające się wykroty), bardzo bogaty florystycznie płat stanowiący mozaikę muraw nawapiennych, skałek i traworośli, dosyć liczna we fragmencie z niewielkimi wychodniami skalnymi i murawami nawapiennymi - kilkanaście kępek, 02.07.2018 r., AZ; 2) Upłaziańska Kopa, ok. 1750-1800, wystawa: NE, nierzadko w płatach wysokogórskich muraw nawapiennych, łącznie nie mniej niż 100 kępek, 30.06.2019 r., MKo, KKK; 3) Kopieniec Wielki, 1270, wystawa: NE, murawa nawapienna z zaroślami jałowca pospolitego, kilka kępek, 26.07.2019 r., AMO.

Carex parviflora - CR, (CR), [EN]; Dolina Litworowa, 1846, wystawa: NW, bogaty nawapienny płat roślinności, będący mozaiką skałek, muraw i traworośli, kilkanaście kępek, turzyca czarna z Dol. Litworowej była już podawana z 1800 i 1835 m n.p.m., przez Delimat (1999) i MiRKa i in. (2008). Opisywane stanowisko znajduje się w wyższej części doliny, co świadczy o szerszym występowaniu tego gatunku na tym obszarze. 15.09.2011 r., AD.

Carex pauciflora - EN, (EN), [EN]; 1) Dolina Gąsienicowa - pomiędzy Litworowym i Zielonym Stawem, 1623, w podmokłym, zatorfionym miejscu, kilka kępek, 18.08.2016 r., AD, PC; 2) Zielony Staw Gąsienicowy, 1679 m. n.p.m., wystawa: NE, torfowisko przy północnym brzegu stawu, kilkanaście generatywnych kęp, 10.09.2016 r., AD; 3) Dolina Rybiego Potoku, ok. 1315, wystawa: N, torfowisko w pobliżu polany Włosienica, pod Granią Żabiego, na skraju zarastającego stawku, kilkadziesiąt kępek na powierzchni kilkudziesięciu $\mathrm{m}^{2}, 13.11 .2018$ r., AZ; 4) Czarny Staw Polski - południowowschodni brzeg, ok. 1723, wystawa: NE, torfowisko przy brzegu stawu, kilkanaście kępek na powierzchni kilkunastu $\mathrm{m}^{2}, 11.09 .2019$ r., AZ; 5) Litworowy Staw, 1621, wystawa: E, torfowisko przy zachodnim brzegu stawu, kilka kępek, 27.10.2019 r., PK.

Cephalanthera longifolia - [VU]; ochrona ścisła, gatunek znany dotychczas w TPN z dwóch stanowisk: Małe Koryciska (Delimat \& Gawryś 2006) i Siwiańskie Turnie (Delimat 2014). 1) Wielkie Koryciska, 1088, wystawa: SE, śródleśna murawa, 38 kwitnących okazów, 20.06.2013 r., PK, SW; 2) Łysa Skałka, 1025, wystawa: SE, w lesie bukowo-jodłowym, jeden kwitnący okaz, 12.06.2019 r., SW.

Cirsium eriophorum - (VU), [VU]; 1) Krokiew - Opalone, nad Kuźnicami, 1224, wystawa: NE, zarastające świerkiem murawy, osiem osobników generatywnych, 29 wegetatywnych na powierzchni ok. 1 ara, 07.10.2015 r., PK; 2) Nosal - grzbiet między szczytem, a Przełęczą Nosalową, 1148, wystawa: S, 02.07.2018 r., PK; 3) Polana Tyrałówka, 1245, wystawa: N, na brzegu koszonej łąki, dwa osobniki generatywne, dwa osobniki wegetatywne, 30.08 .2018 r., AMO; 4) Dolina Lejowa - Pośrednia Kopka, 1080, wystawa: W, strome zbocze, powierzchnia powiatrołomowa (z uprzątniętym drewnem), zarośnięta bujnie przez trawy: Festuca gigantea, Elymus caninus, Calamagrostis arundinacea, Calamagrostis varia, na skraju młodego drzewostanu z modrzewiem obcego pochodzenia (Larix kaempferi i prawdopodobnie Larix xeurolepis), jeden osobnik generatywny, dwa wegetatywne, 07.09.2018 r., AZ; 5) Dolina Chochołowska - Skorusi Żleb, 1421, wystawa: E, wiatrołom świerkowy, pięć osobników generatywnych, 11 osobników wegetatywnych, 30.06.2019 r., AMO; 6) Wierch Poroniec - przy drodze Oswalda Balzera, ok. 1090, wystawa: E, pobocze drogi - za barierkami ochronnymi, ok. $250 \mathrm{~m}$ poniżej (w stronę Łysej Polany) parkingu i wejścia na szlak na Rusinową Polanę trzy osobniki generatywne, cztery wegetatywne, 18.09.2019 r., AZ; 7) Niżnia Polana Kominiarska, 1150, wystawa: N, polana reglowa, jeden osobnik generatywny, 25.11.2019 r., SW.

Cochlearia tatrae - EN, (VU), [EN], ochrona ścisła, kod Natura 2000: 4090*, endemit tatrzański; 1) Wyżni Czarnostawiański Kocioł, 1880-1885, wystawa: E, populacja składa się z dwóch skupisk: pierwsze położone jest na progu kotła (1880 m n.p.m.), wzdłuż małego cieku wodnego płynącego w kierunku wodospadu Dymiąca Woda, drugie - przy dużym głazie, na wypłaszczeniu terenu (mszarnik), tuż powyżej krawędzi kotła (ok. 1885 m n.p.m.). Niżej położone skupienie liczy 50 osobników 
generatywnych, a wyższe 20 osobników generatywnych. Ponadto liczne osobniki wegetatywne oraz siewki. Stanowisko przypomina swoją strukturą i uwarunkowaniami siedliskowymi populację Cochlearia tatrae w Mięguszowieckim Kotle, 09.07.2015 r., GB, PC, AZ, monitoring i określenie liczebności populacji: 20.08.2018 r., SW, AZ; 2) Zadni Mnichowy Stawek, 2072, wystawa: NW, przy małym potoku wypływającym z Zadniego Mnichowego Stawku, mszarnik otoczony piargiem granitowym, pięć osobników generatywnych i kilka osobników wegetatywnych; niewykluczone, że warzucha tatrzańska pojawiła się na tym stanowisku stosunkowo niedawno, bowiem rejon ten jest regularnie penetrowany przez botaników, a pomimo to nie była znana z tego miejsca. Ponadto lokalizacja ta znajduje się na trasie dojścia do objętych monitoringiem populacji na Przełęczy pod Zadnim Mnichem (poprzedni monitoring - 2014 r.) i w Prawym Zachodzie Abgarowicza (poprzedni monitoring - 2015 r.). Może to świadczyć o rozprzestrzenianiu się gatunku w tym rejonie. 20.08.2018 r., SW, AZ; 3) Lewy Zachód Abgarowicza, ok. 2250, wystawa: NW, stromy, zacieniony, wilgotny, mylonitowy żleb z drobnymi piargami, trzy kępy - prawdopodobnie rzeczywista liczebność w Lewym Zachodzie Abgarowicza jest większa, ale ze względu na trudności terenowe nie udało się spenetrować całego żlebu i przylegającego obszaru, 12.09.2019 r., WGR.

Cotoneaster tomentosus - EN, (EN), [EN]; 1) Kopieniec Wielki, 1242, wystawa: SE, murawa nawapienna z luźnymi zaroślami jałowca pospolitego, tuż przy zielonym szlaku turystycznym, jeden owocujący krzew z pędami wyrastającymi w kępie jałowca, 25.08.2017 r., PK.; 2) na stoku Stołów opadającym do Doliny Kościeliskiej, 1145-1180, wystawa: S-SE, na półkach i w szczelinach wapiennej skały, 13 krzewów, 20.06.2018 r., SW; 3) Łysa Skałka, ok. 1050, wystawa: SE, w szczelinie wapiennej skały, jeden krzew, 12.06.2019 r., SW.

Cypripedium calceolus - VU, (EN), [VU], ochrona ścisła, kod Natura 2000: 1902; 1) Dolina nad Capkami, 975, wystawa: NW, krawędź skałki wapiennej ocienionej przez świerki i wierzbę iwę, orograficznie prawe zbocze doliny, jedna kępa: jeden pęd wegetatywny, jeden pęd generatywny, 01.06.2016 r., PK; 2) Dolina Kościeliska - Mały Regiel, 965, wystawa: SW, sztuczny drzewostan świerkowy (częściowo przerzedzony na skutek wiatrołomów i gradacji kornika drukarza) na siedlisku żyznej buczyny karpackiej, stromy stok, cztery kępy, 86 pędów (50 - pędów generatywnych, 36 - pędów wegetatywnych), 22.05.2018 r., WT, SW, AZ; 3) Dolina Białego - Spaleniec, 1157, wystawa: SE, buczyna, stromy stok, dwie kępy: pierwsza - cztery pędy wegetatywne, jedna siewka, druga - dwa pędy wegetatywne, 19.06.2018 r., AZ; 4) Dolina Lejowa, ok. 935, wystawa: SE, lesiste zbocze po orograficznie lewej stronie Doliny Lejowej, w pobliżu jej wylotu, kilka metrów ponad szlakiem, częściowo przerzedzony sztuczny drzewostan świerkowy na siedlisku żyznej buczyny karpackiej, dziewięć kęp, 170 pędów (112 - pędów generatywnych, 58 - pędów wegetatywnych), 07.06.2019 r., FZ, SW, AZ; 5) Upłaziańska Kopa (Ryc. 1), 1770, wystawa: $\mathrm{NE}$, wysokogórska murawa nawapienna, dwie kępy, łącznie 17 pędów, w tym 10 generatywnych; to obserwowane od sierpnia 2010 roku stanowisko zdecydowanie, bo aż o prawie $500 \mathrm{~m}$ przesuwa zasięg wysokościowy tego gatunku w Polsce. Do tej pory za najwyżej położone stanowisko uważano Kopieniec Wielki - 1280 (KAŹMIERCZAKOwa i in. 2014). 30.06.2019 r., MKo, KKK; 6) Zadnie Kamienne, 1522 i 1555, wystawa: S-SE, w subalpejskich, bogatych florystycznie murawach nawapiennych, m.in. z Astragalus australis, niżej położona kępa: 30 pędów (22 - pędy generatywne, 8 - pędów wegetatywnych), wyżej położona kępa: 8 pędów ( 4 - pędy generatywne, 4 - pędy wegetatywne), jest to kolejne w tym rejonie, obok populacji na Upłaziańskiej Kopie, wysokogórskie stanowisko obuwika w Tatrach. 12.08.2019 r., AZ; 7) Dolina za Bramką - Pośredni Wierszyk, poniżej Jasiowych Turni, 980, wystawa: SW, buczyna karpacka, jeden okaz generatywny - kwitnął, ale nie zawiązał owoców, 21.08.2019 r., AMO.

Draba carinthiaca - CR, (CR), [CR]; Skrajny Wołoszyn, ok. 2020, wystawa: SE, w szczelinach mylonitowej ściany skalnej, ponad stromym żlebem opadającym do Dol. Roztoki, 12 kępek z tego osiem z pędami generatywnymi, 27.09.2019 r., SW, AZ.

Draba dubia - EN, (EN), [EN]; Wołowiec, ok. 1700, wystawa: E, w szczelinach mylonitowej ściany skalnej, u podstawy masywu Wołowca ponad Doliną Wyżnią Chochołowską, kilka kępek z licznymi pędami generatywnymi, 04.07.2019 r., AZ.

Draba tomentosa - EN, (VU), [EN]; Tomanowe Stoły, 1811 i 1877, wystawa: NW i NE, w szczelinach ścian skalnych, stanowiska znajdują się niedaleko grani głównej, od północnej strony, przed Małą 


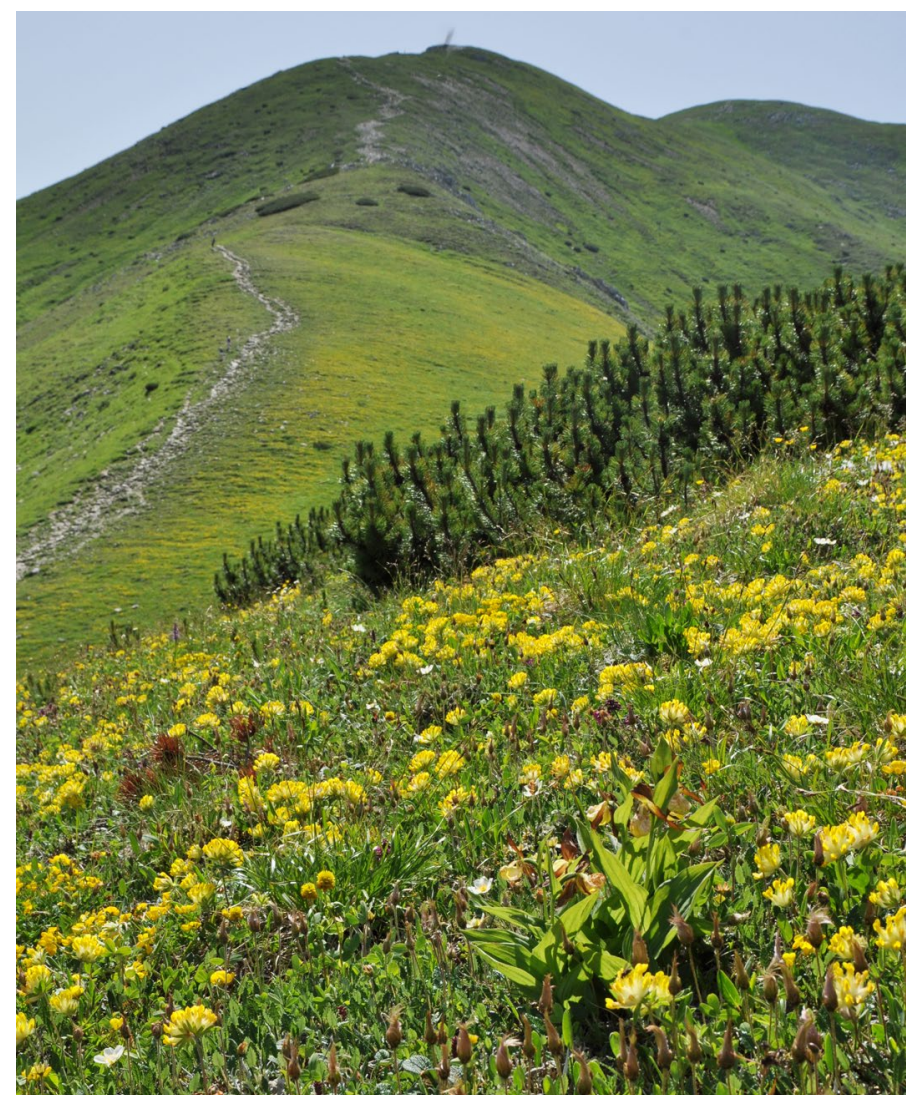

Ryc. 1. Kępa Cypripedium calceolus w wysokogórskiej murawie nawapiennej z Anthyllis alpestris i Dryas octopetala na Upłaziańskiej Kopie (1770 m n.p.m.) (30.06.2019 r., fot. M. Kozak)

Fig. 1. Cypripedium calceolus in subalpine sward with Anthyllis alpestris and Dryas octopetala at Upłaziańska Kopa Mt. (1770 m a.s.1.) (30 June 2019; photo by M. Kozak)

Przełączką, oddzielającą Stoły od Ciemniaka, w obu miejscach po kilka kęp z pędami generatywnymi, 15.09.2013 r., AD.

Epipactis palustris - [NT], ochrona ścisła, gatunek znany dotychczas w TPN z jednego stanowiska: Lichajówki (MireK i in. 2012); 1) Dolina Jaworzynki, ok. 1180, wystawa: E, zarastająca świerkami wilgotna murawa nawapienna z dużym udziałem Calamagrostis varia, 11 roślin z tego dwie kwitnące, 07.08.2013 r., SW; 2) Wyżnia Dudowa Rówień, ok. 1205, wystawa: SW, na łące reglowej w wilgotnym płacie opanowanym przez Chaerophyllum hirsutum, dwa kwitnące okazy, 19.07.2017 r., SW; 3) Stasikówka - Głębokie, 852, wystawa: N, skraj nieużytkowanych, wilgotnych zarośli przy drodze gruntowej, w pobliżu strażniczówki, 22 owocujące okazy i kilkanaście płonnych, 23.08.2019 r., PK.

Epipogium aphyllum - CR, (EN), [CR], ochrona ścisła; 1) Suchy Żleb, ok. 1093, wystawa: NE, lesiste zbocze po orograficznie lewej stronie Suchego Żlebu, kilkanaście metrów powyżej dna żlebu, siedlisko żyznej buczyny karpackiej, dwa pędy generatywne, 22.08.2012 r., pięć pędów generatywnych, 04.08.2019 r., AD. E. aphyllum był już zbierany w Suchym Żlebie przez Pawłowskiego (okaz w KRAM, leg. B. Pawłowski w 1950 r.) i obserwowany przez BINKIEWICZA i in. (2017). Jednakże dotychczas opisane stanowiska znajdują się na wysokości 1000-1040; 2) Gubalec, 1170-1295, wystawa: SW, bór świerkowy, pięć pędów generatywnych, 11.08.2014 r., SW; 3) Żar, 1340, wystawa: SW, bór świerkowy, 28 pędów generatywnych, 11.08.2014 r., SW; 4) wylot Doliny Chochołowskiej (Ryc. 2), 917, wystawa: NE, las jodłowo-świerkowy 
na terasie na lewym orograficznie brzegu Potoku Chochołowskiego, ok. $40 \mathrm{~m}$ od północnej granicy TPN, 11 pędów generatywnych, wśród gatunków towarzyszących m.in. Goodyera repens, 28.07.2016 r., PK; 5) Dolina Białki - Roztocka Czuba, 1084, wystawa: NE, łagodny stok przy wychodni skalnej, na granicy luki w świerczynie, poniżej szlaku (droga Oswalda Balzera prowadząca nad Morskie Oko) - ok. 45 m, kilka pędów generatywnych 24.07.2017 r., MKa, MW; 6) Sarni Żleb, 1110, wystawa: NW, młody drzewostan bukowo-świerkowy z domieszką jodły (siedlisko żyznej buczyny), nieliczny - kilka pędów generatywnych, być może jest to stanowisko tożsame z opisywanym przez KotUlE (1889-1890) z Sarniej Skały (Mała Świnnica) z wysokości 1096 m n.p.m., 14.07.2018 r., JB; 7) Dolina Białego - Kopa nad Białym, 993, wystawa: E; żyzna buczyna karpacka (płat z dominacją buka), dwa pędy generatywne wyrastające w odległości $15 \mathrm{~cm}$ od siebie, 22.07.2019 r., PK; 8) Filipczański Wierch, 1010-1100, wystawa: NW-W, żyzna buczyna z udziałem jaworu, 25 pędów generatywnych, 25.07.2019 r., MKo.

Gagea minima - (EN); 1) Polana Pisana, 1055, wystawa: W, łąka, kilkanaście kwitnących roślin na powierzchni ok. 10 m² $^{2}$ 31.05.2015 r., SW; 2) Przysłop Miętusi, 1130-1197, wystawa: W-SW, łąka, kilkadziesiąt kwitnących roślin w pięciu płatach zlokalizowanych w różnych częściach polany, 24.04.2014 r., SW; 3) Przednia Kopa Sołtysia, 1310, wystawa: E, łąka, kilkadziesiąt kwitnących roślin na powierzchni ok. $100 \mathrm{~m}^{2}$, 06.05.2014 r., SW; 4) Płaśnia, 1248, płaskie miejsce na łące w pobliżu ruin szałasów pasterskich, kilkaset kwitnących roślin, 06.05.2014 r., SW, 5) Szałasiska w Kopach Sołtysich, 1140, łąka, kilkaset kwitnących roślin, 06.05.2014 r., SW; 6) Polana Waksmundzka, 1370, wystawa: W, na łące w rejonie dawnych szałasów pasterskich, kilkaset kwitnących roślin, 06.05.2014 r., SW.

Gnaphalium hoppeanum - VU, (VU), [VU]; Wyżnia Kondracka Przełęcz, 1780, wystawa: SE, murawa wysokogórska na wapieniu, kilkadziesiąt pędów, 05.08.2010 r., MKo.

! Hedera helix - roślina częsta w Polsce, także jako sadzona i dziczejąca (RUTKOWSKI 2007). W obrębie Tatr gatunek bardzo rzadki, znany tylko z południowej strony Tatr Wysokich (PAWŁOWSKI 1956) oraz Zachodnich (rejon wylotu Doliny Jałowieckiej, wylotowy odcinek Doliny Suchej Sielnickiej, P. Kauzal, mat. niepubl. z lat 2015-2016). Z obszaru Rowu Podtatrzańskiego MireK (2016) podaje go tylko jako sadzonego, lecz lokalnie dziczejący w bliskości stanowisk sadzonych. Nosal, 948, wystawa: W, ok. 50-letni drzewostan jodłowo-jaworowo-bukowy z domieszką świerka na siedlisku żyznej buczyny karpackiej w dolnej części zbocza, w bezpośredniej bliskości granicy TPN, jeden okaz - pęd ok. $50 \mathrm{~cm}$ długości płożący się po ziemi, stanowisko znajduje się w odległości $100 \mathrm{~m}$ od najbliższych zabudowań z ogrodami (osiedle Bystre). W związku z faktem, iż na terenie Zakopanego spotyka się owocujące okazy Hedera helix w zieleni miejskiej, np. przy willi Oksza (P. Kauzal, mat. niepubl., 2018), można przypuszczać, że na opisywanym stanowisku roślina została najprawdopodobniej zawleczona przez ptaki. 03.07.2018 r., PK.

Ledum palustre - (VU), ochrona częściowa; Dolina Iwanowska - Ornak, ok. 1245, wystawa: N, torfowisko stokowe, silnie porośnięte przez kosodrzewinę, kilkanaście metrów od szlaku z Hali Ornak na Przełęcz Iwaniacką, jedna kępa z siedmioma pędami (najwyższy ok. $20 \mathrm{~cm}$ ), stanowisko znalezione w 1948 r. (RADWAŃSKA-PARYSKA 1950) i od tego czasu nie potwierdzone (KocZur i in. 2008). Pierwotnie rosło tutaj kilka bujnych, do 0,6 m wysokich, kwitnących krzewów. W 2019 r. znaleziono zaledwie jeden, nieduży i silnie przygłuszony przez kosówkę krzew. 31.10.2019 r., AZ.

! Lemna minor - na obszarze Rowu Podtatrzańskiego występująca bardzo rzadko - podana z zaledwie dwóch stanowisk na terenie Zakopanego (MireK 2016). Jaszczurówka, 897, niewielki i płytki, ocieniony zbiornik wodny zasilany drobnym ciekiem położony na E od wylotu Doliny Olczyskiej, pomiędzy podnóżem zbocza, a Drogą Oswalda Balzera, płat o powierzchni ok. 3 m², 12.08.2015 r., PK.

Ophrys insectifera - VU, (EN), [VU], ochrona ścisła; 1) Szerokie Kalackie, ok. 1210, wystawa: SE, murawa nawapienna, 91 kwitnących roślin, stanowisko znane wcześniej służbom TPN, 30.05.2011 r., SW; 2) Klinowa Czuba, 1094, wystawa: SW, przerzedzony drzewostan świerkowo-jodłowy z łanowo występującym trzcinnikiem leśnym w runie, prawy brzeg płytkiego, wilgotnego żlebku, trzy kwitnące rośliny, 08.07.2014 r., PK; 3) Krokiew - Szeroki Żleb, 1117, wystawa: SE, murawa nawapienna, jedna kwitnąca roślina, 25.06.2015 r., PK; 4) Dolina Bystrej - Krokiew, 1109, wystawa: SE, zarastająca świerkiem murawa nawapienna ponad Polaną Kuźnicką, 16 kwitnących roślin, jedna płonna, 01.06.2016 r., PK; 5) Dolinka do Bani, 1196, wystawa: S, murawa nawapienna, dwie kwitnące rośliny, 16.06.2016 r., SW; 6) Boczań Kasprowy, 1265, wystawa: SW, murawa nawapienna, pięć kwitnących roślin, 30.05.2018 r., 


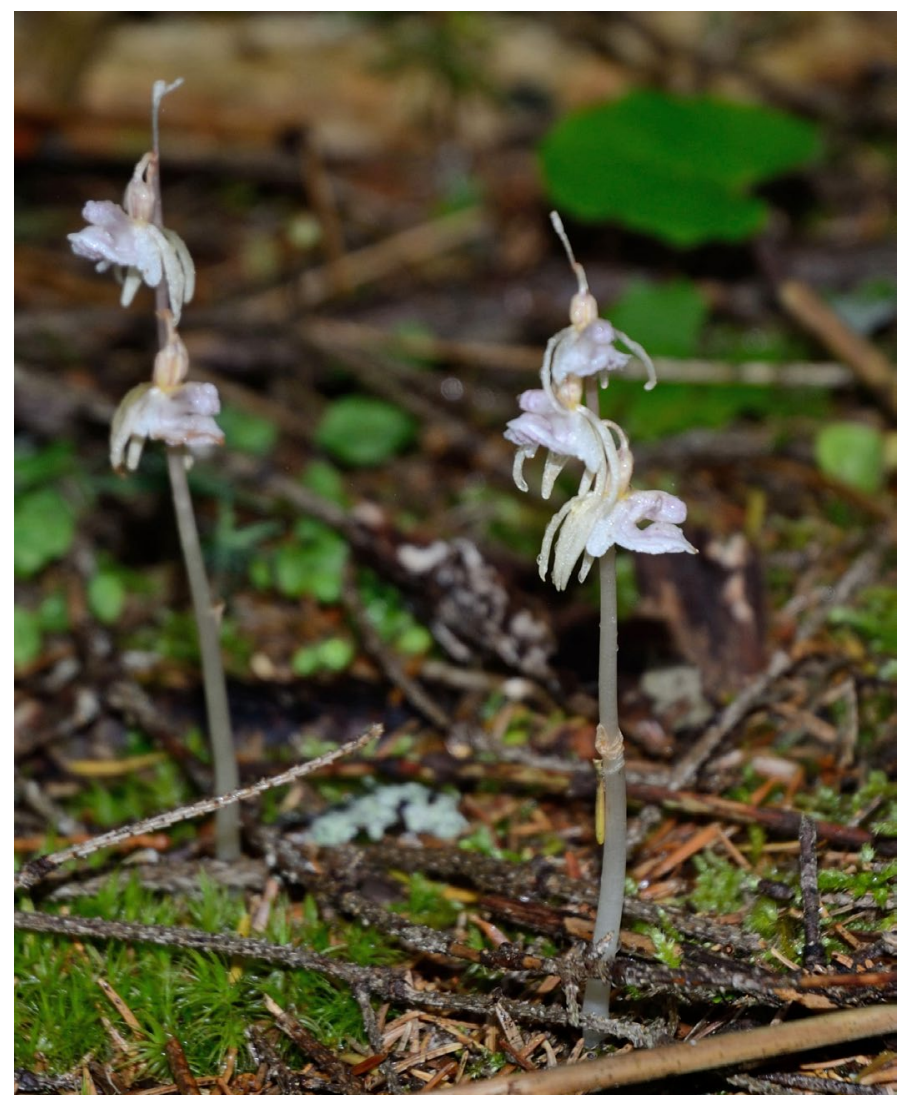

Ryc. 2. Epipogium aphyllum w lesie jodłowo-świerkowym na terasie Potoku Chochołowskiego, w pobliżu wylotu Doliny Chochołowskiej (917 m n.p.m.) (28.07.2016 r., fot. P. Kauzal)

Fig. 2. Epipogium aphyllum in Abies alba-Picea abies forest on the Potok Chochołowski stream terrace, near the mouth of the Dolina Chochołowska valley (917 m a.s.1.) (28 July 2016; photo by P. Kauzal)

SW; 7) Dolina Strążyska, na zachód od Sarniej Skały, 1160, wystawa: W, niewielki fragment murawy, cztery owocujące osobniki, 16.07.2018 r., JB.

Oxycoccus palustris - (VU); Dolina Rybiego Potoku, ok. 1315, wystawa: N, torfowisko w pobliżu polany Włosienica, pod Granią Żabiego, przy zarastającym stawku, dosyć liczna, kilkadziesiąt pędów na powierzchni kilkuset $\mathrm{m}^{2}, 13.11 .2018$ r., AZ.

Pedicularis hacquetii - VU, (VU), [VU]; Wielki Piarg, 1563-1570, wystawa: N, ziołorośla pod ścianą masywu Mięguszowieckich Szczytów, w kilku grupach po kilka kwitnących roślin, 08.07.2012 r., AD.

Poa nobilis - DD, (DD), [DD], endemit tatrzański; 1) Wyżni Czarnostawiański Kocioł, 1935, wystawa: NE, wyleżyska śnieżne, przy wilgotnym piargu mylonitowo-granitowym, kilka kęp zajmujących pow. kilkudziesięciu m², 20.08.2018 r., SW, AZ; 2) Żleb pod Mnichem, ok. 1700-2040, wystawa: N-NE-E, wilgotne piargi granitowo-mylonitowe, wyleżyska śnieżne, dosyć liczna, kilkadziesiąt kęp zajmujących łącznie ponad $100 \mathrm{~m}^{2}, 20.08 .2018$ r., SW, AZ; 3) Kotelnica, ok. 1910, wystawa: N, szczeliny skalne w stromym, wilgotnym i zacienionym progu mylonitowego żlebu opadającego z Niżniej Kotelnicowej Ławki oraz w sąsiadującym piargu $\mathrm{z}$ drobnym materiałem skalnym, nieliczna - kilka kęp zajmujących kilka $\mathrm{m}^{2}$, w pobliżu liczna Poa alpina var. vivipara. 11.09.2019 r., AZ, 4) Kopa nad Wrotami, ok. 1920-1945, wystawa: NE, wyleżyska śnieżne i traworośla u podstawy ściany skalnej, miejscami również obrzeża piargu granitowego, liczna - kilkanaście kęp zajmujących kilkanaście m², 11.09.2019 r., AZ. 
! Potamogeton berchtoldii - [DD], najbliższe stanowiska gatunku znajdują się w Kotlinie OrawskoNowotarskiej (ZALEwska-GaŁosz 2008). 1) Małe Żabie Oko, 1389, pojedynczy, drobny okaz, prawdopodobnie przeniesiony przez wodę z Małego Morskiego Oka - oznaczenie potwierdziła Joanna Zalewska-Gałosz 19.09.2014 r., PK; 2) Małe Morskie Oko, 1393, kilka tysięcy okazów - oznaczenie potwierdziła Joanna Zalewska-Gałosz, 27.09.2019 r., AMO.

Salvia verticillata - gatunek znany z Tatr Polskich ze stanowisk: „Strążyska” i „Dolina Ku Dziurze”, przy czym obie lokalizacje dotyczą „krainy regla dolnego” (KотUla 1889-1890). Z obszaru Rowu Podtatrzańskiego podawany jako dość częsty (MIREK 2016). Dolina Jaworzynki, 1105, wystawa: SW, skraj Polany Jaworzynki, przy prawym orograficznie brzegu żlebu opadającego spod Czerwonej Gliny, jedna kępa z siedmioma pędami generatywnymi (początek kwitnienia), kilkanaście metrów poniżej stanowiska odnotowano występowanie m.in.: Malaxis monophyllos oraz Gladiolus imbricatus, 07.07.2018 r., PK.

Saussurea pygmaea - EN, (EN), [EN], 1) Hińczowa Przełęcz, ok. 2325, wystawa: E, w wilgotnych szczelinach skalnych opadających z Cubryny i piargach granitowo-mylonitowych, kilka kęp generatywnych, 27.07.2013 r., AD, 2) Kamienista, 2020, wystawa: N-NW, w murawie z Juncus trifidus i Oreochloa disticha, 99 różyczek liściowych z tego siedem z kwiatostanami, 30.07.2016 r., SW; 3) Skrajny Wołoszyn, ok. 2010, wystawa: SE, na mylonitowej skale i w murawie u podnóża tejże skały, ponad stromym żlebem opadającym do Dol. Roztoki, cztery pędy generatywne w dwóch kępach, 27.09.2019 r., SW, AZ.

Senecio aurantiacus - (EN), [EN]; Upłaziańska Kopa, ok. 1745, wystawa: SW, murawa subalpejska na rozległym zboczu, poprzetykana kępami kosówki, kilkanaście pędów generatywnych w dwóch kępach, 12.08.2019 r., AZ.

! Senecio sylvaticus - częsty w Polsce, najbliższe znane stanowisko znajduje się w Zębie na Pogórzu Przedtatrzańskim (dane z bazy ATPOL, informacja A. Zając 2020). 1) na grzbiecie biegnącym od Cisowej Turni nad Małą Doliną Suchą, 1118, wystawa: E, w żyznej jedlinie (drzewostan częściowo przerzedzony - wiatrowały), pojedyncze generatywne okazy, 02.08.2018 r., AMO; 2) Skrajna Rosocha - nad Małą Doliną Suchą, 1126, wystawa: NW, w odległości ok. 400 m od poprzedniego stanowiska, w żyznej jedlinie, pojedyncze generatywne okazy, 20.09.2019 r., AMO.

! Sonchus arvensis - pospolity w Polsce niżowej, jednakże na polskim Podtatrzu stosunkowo rzadki. Znany zaledwie z kilkunastu stanowisk o charakterze synantropijnym w Rowie Podtatrzańskim. Najbliżej położone stanowisko znajduje się w okolicach Gronika w Kościelisku (MIREK 2016). W TPN pojawia się na siedliskach typowo synantropijnych, takich jak pobrzeża dróg (szlaków turystycznych i dróg leśnych) lub w sztucznych drzewostanach, znajdujących się w strefie ochrony krajobrazowej, w których wykonywane są prace leśne. Jego rozprzestrzenianie się na terenie Parku prawdopodobnie związane jest z działalnością człowieka. 1) Dolina Lejowa - ponad skałkami w Między Ścianach, 1022, wystawa: E, sztuczny drzewostan świerkowy z domieszką jodły i buka (częściowo przerzedzony - wiatrowały) na siedlisku żyznej buczyny, górna część (przy grzbiecie biegnącym z Cisowej Turni w kierunku Między Ścian) stromego stoku opadającego do Dol. Lejowej, nieliczny - kilka osobników wegetatywnych, 02.08.2018 r., AMO; 2) Dolina Chochołowska - nad Potokiem Chochołowskim, niedaleko od wylotu Małych Korycisk, 950, przy drodze leśnej, kilka osobników wegetatywnych, 14.08.2018 r., AMO; 3) zbocze opadające od Polany Jaworzyny do Doliny Długiej, 1180, wystawa: N, sztuczny drzewostan świerkowy na żyznym siedlisku, kilka osobników wegetatywnych, 12.08 .2018 r., AMO; 4) Dolina Tomanowa, przy czarnym szlaku ze schroniska na Małej Polance Ornaczańskiej nad Smreczyński Staw, 1142, przydroże, kilka osobników wegetatywnych, jeden osobnik generatywny, 31.08.2019 r., AMO; 5) Dolina Miętusia, przy czarnym szlaku (Ścieżka nad Reglami), 1015, przydroże, kilkanaście osobników, w tym kilka generatywnych, 13.09.2019 r., AMO.

Sorbus chamaemespilus - VU, (VU), [VU]; 1) Stoły, 1323, wystawa: S, trawiaste zbocze (dominacja Calamagrostis arundinacea) porośnięte luźnym drzewostanem świerkowym, jeden krzew, 25.07.2013 r., PK; 2) Dolina Sucha między Suchym Wierchem, a Zameczkami, 1218, wystawa: NW, trawiaste dno dolinki, kilkadziesiąt m ponad Ścieżką nad Reglami, jeden krzew, 29.09.2016 r., PK; 3) na stoku Stołów opadającym do Doliny Kościeliskiej, 1170, wystawa: SE, na półce skalnej jeden krzew, 20.06.2018 r., SW; 4) Dolina Waksmundzka - próg Świstówki Waksmundzkiej, 1710, wystawa: E, strome zbocze, traworośla, murawy subalpejskie, cztery krzewy, 16.09.2018 r., AZ; 5) Świstówka Roztocka, ok. 1800, wystawa: 
$\mathrm{NE}$, rozległe zbocze pokryte borówczyskiem, przy szlaku, jeden krzew o wysokości ok. 0,5 m z licznymi kwiatostanami, 25.06.2019 r., AZ.

! Typha latifolia - rzadka na terenie Rowu Podtatrzańskiego (stwierdzona w czterech kwadratach $1 \mathrm{~km}$ $\times 1 \mathrm{~km}$ ) (MireK 2016). 1) Gronik, 943, wystawa: W, przydrożny rów (przy E krawędzi ul. Strzelców Podhalańskich), niewielki płat, 22.06.2017 r., PK. Być może jest to stanowisko uwzględnione przez MiRKA (2016), jednak z uwagi na brak opisu, a jedynie zaznaczenie w atlasie rozmieszczenia kwadratu $1 \mathrm{~km} \times 1 \mathrm{~km}$, który obejmuje opisaną lokalizację, nie można tego rozstrzygnąć; 2) Polana Bafiówki, 858, wystawa: NE, podmokła część polany u podnóża zbocza, zwarty płat o powierzchni ok. $10 \mathrm{~m}^{2}$, 19.08.2019 r., PK. Najbliższe znane z literatury stanowisko to Poronin, 750 m n.p.m. (MireK 2016).

Vincetoxicum hirundinaria - gatunek znany dotychczas w TPN z trzech stanowisk: „Kościeliska” (GrZegorzeK 1868), Dolina Białego (PięKoś-Mirkowa i in. 1996), Dolina Ku Dziurze (Delimat 2001). Stanowisko podane przez Grzegorzka nie było nigdy potwierdzone i w późniejszych pracach uważano je za niepewne (Pį̨Koś-Mirkowa i in. 1996). Pod Raptawicką Turnią w dolinie Kościeliskiej, 1125-1168, wystawa: S, murawa nawapienna, sześć kwitnących kęp, 12.07.2016 r., SW.

Woodsia alpina - CR, (CR), [CR]; 1) Wanta - pomiędzy Skrajnym Wołoszynem, a Zagonnym Wierchem, 1950, wystawa: SE, szczelina, u podstawy ściany skalnej, jedna kępka, 27.09.2019 r., SW, AZ; 2) Zagonny Wierch (masyw Wołoszyna) (Ryc. 3), 1960, wystawa: E, w szczelinach skalnych, cztery kępki, 27.09.2019 r., SW, AZ.

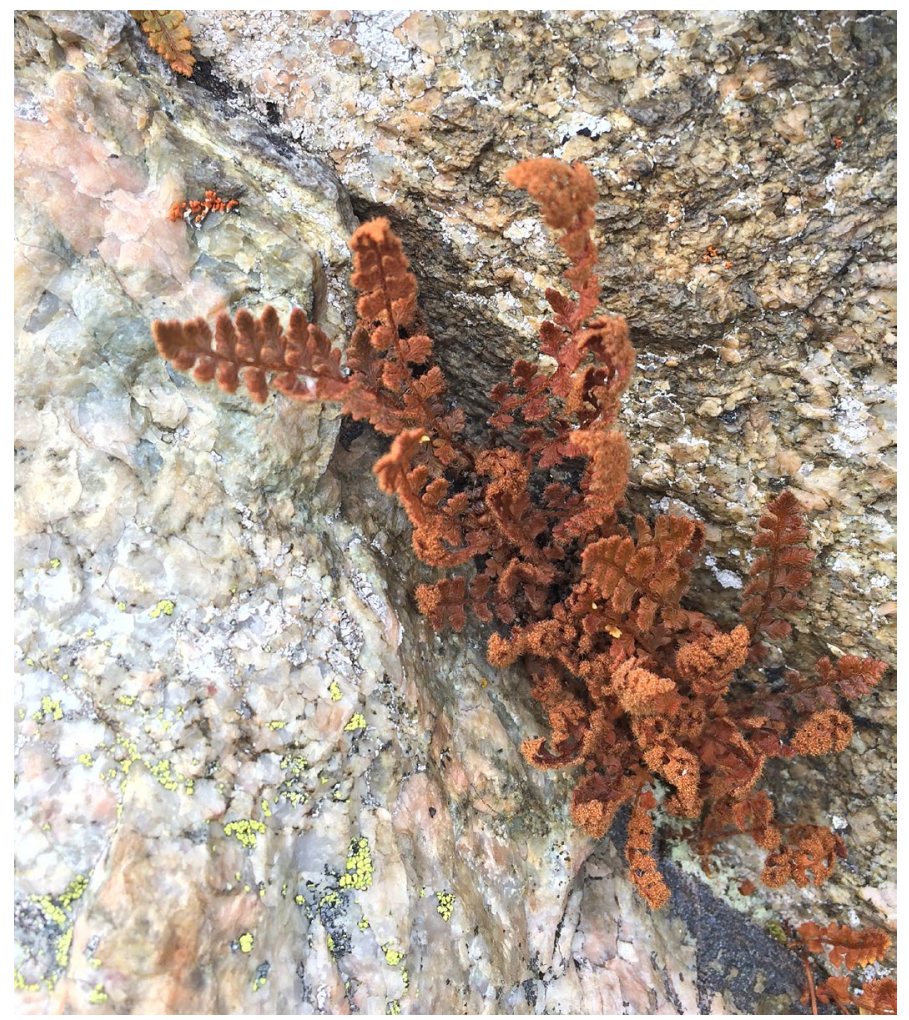

Ryc. 3. Woodsia alpina w szczelinach skalnych Zagonnego Wierchu w masywie Wołoszyna (1960 m n.p.m.) (27.09.2019 r., fot. A. Zięba)

Fig. 3. Woodsia alpina in rock crevices at Zagonny Wierch Mt. in the Wołoszyn massif (1960 m a.s.1.) (27 September 2019; photo by A. Zięba) 


\section{PODSUMOWANIE}

Przeprowadzone w ostatnich latach liczne badania terenowe, które objęły powierzchnię całego TPN, stanowią wkład do lepszego poznania flory Parku. W latach 2010-2019 stwierdziliśmy 130 nowych stanowisk 41 taksonów (w tym osiem nowych dla TPN) i potwierdziliśmy jedno stanowisko gatunku, które nie było od 1950 r. odnalezione (Ledum palustre). Specyfika przeprowadzonych projektów zakładała penetrację terenów trudnodostępnych oraz pozornie nieatrakcyjnych pod kątem botanicznym. Doprowadziło to do odnalezienia nowych stanowisk bardzo rzadkich roślin, takich jak m.in. Cochlearia tatrae, Draba carinthiaca, D. dubia, czy Woodsia alpina, oraz poszerzenia wiedzy na temat rozmieszczenia taksonów, dla których do tej pory dysponowano małą liczbą danych (klasyfikowane w ,,czerwonych” księgach i listach z kategorią DD - data deficient), jak Arctium nemorosum i Poa nobilis.

Ponadto udało się stwierdzić nowe gatunki roślin dla flory TPN. Są to z reguły taksony pospolite w Polsce, występujące głównie na niżu, które do tej pory nie były znane z Tatr. Pojawianie się tych roślin może być częściowo związane z powolnym przesuwaniem się gatunków niżowych w wyższe położenia górskie w związku ze zmieniającymi się warunkami klimatycznymi (KLANDERUd \& BIRKS 2003; CZORTEK i in. 2018). Wpływ na ten proces, w szczególności w przypadku antropofitów, może mieć również znaczna powierzchnia obszarów w reglu dolnym, które uległy w ostatnim czasie różnorakim zaburzeniom. Na tych terenach prowadzone są działania ochronne związane m.in. z przebudową dolnoreglowych monokultur świerkowych na mieszane drzewostany z bukiem, jodłą, jaworem i domieszką świerka. Niewykluczone, że część tych gatunków została przypadkowo zawleczona podczas tych prac.

Podziękowania. Składamy podziękowania dr hab. Joannie Zalewskiej-Gałosz z Instytutu Botaniki Uniwersytetu Jagiellońskiego za potwierdzenie oznaczenia Potamogeton berchtoldii oraz prof. dr. hab. Adamowi Zającowi z Instytutu Botaniki Uniwersytetu Jagiellońskiego za udostępnienie danych z bazy ATPOL dla gatunku Senecio sylvaticus. Badania częściowo dofinansowano ze środków Funduszu Leśnego, przekazanych w latach 2018 i 2019 Tatrzańskiemu Parkowi Narodowemu przez Państwowe Gospodarstwo Leśne „Lasy Państwowe”.

\section{LITERATURA}

Balcerkiewicz S. 1984. Roślinność wysokogórska Doliny Pięciu Stawów Polskich w Tatrach i jej antropogeniczne przemiany. s. 191. Wydawnictwo Naukowe UAM, Seria Biologia 25, Poznań.

Berdau F. 1890. Flora Tatr, Pienin i Beskidu Zachodniego. s. 827. Kasa im. J. Mianowskiego, Warszawa.

BinKIEwICZ B. 2014. Nowe i potwierdzone stanowiska storzana bezlistnego Epipogium aphyllum (Orchidaceae) w Tatrzańskim Parku Narodowym. - Chrońmy Przyrodę Ojczystą 70(3): 250-258.

Binkiewicz B., Pięta M. \& Pięta G. 2017. Rozmieszczenie, zasoby oraz zagrożenia Epipogium aphyllum i Listera cordata (Orchidaceae) w lasach Tatrzańskiego Parku Narodowego. - Fragmenta Floristica et Geobotanica Polonica 24(1): 85-98.

Bodziarczyk J., Szwagrzyk J., ZwiJacZ-Kozica T., ZięBa A., SzewczyK J. \& GaZda A. 2019. Struktura drzewostanów Tatrzańskiego Parku Narodowego - wyniki inwentaryzacji z lat 2016-2017. - Leśne Prace Badawcze 80(1): 13-21. 
Czortek P., Delimat A., Dyderski M. K., ZięBa A., Jagodziński A. M. \& Jaroszewicz B. 2017. Climate change, tourism and historical grazing influence the distribution of Carex lachenalii Schkuhr - A rare arctic-alpine species in the Tatra Mts. - Science of the Total Environment 618: 1628-1637.

CZortek P., Kapfer J., Delimat A., Eycott A.M., Grytnes J.-A., Orczewska A., Ratyńska A., Zięba A. \& JARoszewicz B. 2018. Plant species composition shifts in the Tatra Mts as a response to environmental change: a resurvey study after 90 years. - Folia Geobotanica 53: 333-348.

Delimat A. 1999. Nowe stanowiska czterech rzadkich gatunków roślin w Tatrzańskim Parku Narodowym. - Chrońmy Przyrodę Ojczystą 55(4): 74-77.

Delimat A. 2001. Nowe stanowiska rzadkich roślin w Tatrzańskim Parku Narodowym. - Chrońmy Przyrodę Ojczystą 57(4): 88-93.

Delimat A. 2014. Nowe stanowisko rzadkiego storczyka - buławnika mieczolistnego Cephalanthera longifolia w Tatrzańskim Parku Narodowym. - Chrońmy Przyrodę Ojczystą 70(5): 468-471.

Delimat A. \& Borucki T. 2009. Draba siliquosa (Brassicaceae) w Tatrach Wysokich - nowy gatunek we florze Polski. - Fragmenta Floristica et Geobotanica Polonica 16(1): 39-44.

Delimat A. \& Gawryś W. 2006. Cephalanthera longifolia (Orchidaceae) - nowy gatunek dla Tatr Polskich. - Fragmenta Floristica et Geobotanica Polonica 13(2): 247-251.

GRZEGORZEK W. 1868. Spis roślin w różnych okolicach Galicji zebranych. - Sprawozdania Komisji Fizyjograficznej Towarzystwa Naukowego Krakowskiego 2: 34-51.

Kaźmierczakowa R. \& Perzanowska J. 2001. Notatki florystyczne z Pienin. - Fragmenta Floristica et Geobotanica Polonica 8: 3-9.

KAŹmierczakowa R., Zarzycki K. \& Mirek Z. (red.). 2014. Polska czerwona księga roślin. s. 895. Instytut Ochrony Przyrody Polskiej Akademii Nauk, Kraków.

Kaźmierczakowa R., Bloch-OrŁowska J., Celka Z., Cwener A., Dajdok Z., Michalska-Hejduk D., PAWLIKOWSKi P., SZCZĘ́ŚNIAK E. \& ZiARNeK K. 2016. Polska czerwona lista paprotników i roślin kwiatowych. s. 44. Instytut Ochrony Przyrody Polskiej Akademii Nauk, Kraków.

KLANDERUD K. \& BirKs H. J. B. 2003. Recent increases in species richness and shifts in altitudinal distributions of Norwegian mountain plants. - The Holocene 13(1): 1-6.

Koczur A., PięKoś-Mirkowa H., Mitka J. \& Szary A. 2008. Bagno zwyczajne Ledum palustre. - W: Z. Mirek \& H. PięKoś-Mirkowa (red.), Czerwona księga Karpat polskich. Rośliny naczyniowe, s. 169-171. Instytut Botaniki im. W. Szafera Polskiej Akademii Nauk, Kraków.

KosińSKi M. 1999. Zbiorowiska roślinne piargów Tatrzańskiego Parku. - Prace Botaniczne 32: 1-75.

KотUla B. 1889-1890. Rozmieszczenie roślin naczyniowych w Tatrach. s. 512. Nakładem Wydziału Matematyczno-Przyrodniczego Akademii Umiejętności, Kraków.

KRUK J. 2012. Nowe stanowiska przymiotna alpejskiego Erigeron alpinus subsp. intermedius i starca pomarańczowego Senecio aurantiacus w Tatrach. - Chrońmy Przyrodę Ojczystą 68(3): 205-208.

Kruk J., Sliwinska E., Grabowska-Joachimiak A., Kromer K. \& Szymańska R. 2015. Woodsia pulchella in the Western Carpathians: a relict species at the northern limits of its distribution. - Annales Botanici Fennici 52: 193-201.

ŁoBARZEWSKA A. 1984. Odnalezione i nowe stanowiska rzadkich taksonów roślin naczyniowych w Tatrzańskim Parku Narodowym. - Chrońmy Przyrodę Ojczystą 40(3): 60-65.

Łyser S. 1974. Sosna Pinus silvestris L. - W: S. Myczkowski (red.), Rodzime drzewa Tatr. Część 1. - Studia Ośrodka Dokumentacji Fizjograficznej PAN 3: 87-110.

Mirek Z. 2016. Rośliny naczyniowe Rowu Podtatrzańskiego. Flora i atlas rozmieszczenia. s. 314. Instytut Botaniki im. W. Szafera Polskiej Akademii Nauk, Kraków. 
Mirek Z. \& PięKoś-Mirkowa H. 1985. Nowe lub rzadkie gatunki roślin naczyniowych w Tatrzańskim Parku Narodowym. - Chrońmy Przyrodę Ojczystą 41(2): 54-57.

Mirek Z. \& PięKoś-Mirkowa H. 1996. Rośliny kwiatowe i paprotniki. - W: Z. Mirek (red.), Przyroda Tatrzańskiego Parku Narodowego, s. 275-315. Tatrzański Park Narodowy, Zakopane.

Mirek Z. \& Pięroś-Mirkowa H. 2005. Szata roślinna Tatr na tle obszarów górskich Europy. - W: Z. MireK \& B. GodziK (red.), Przyroda Tatrzańskiego Parku Narodowego a człowiek. Tatrzański Park Narodowy na tle innych górskich terenów chronionych. 2. Nauki biologiczne, s. 11-27. Tatrzański Park Narodowy, Zakopane.

Mirek Z. \& Pięroś-Mirkowa H. (red.). 2008. Czerwona księga Karpat polskich. Rośliny naczyniowe. s. 615. Instytut Botaniki im. W. Szafera Polskiej Akademii Nauk, Kraków.

Mirek Z. \& PięKoś-Mirkowa H. 2010. Fitogeograficzna analiza endemitów roślin naczyniowych Tatrzańskiego parku narodowego. - W: Z. MireK (red.), Przyroda Tatrzańskiego Parku Narodowego a człowiek. Nauka a zarządzanie obszarem Tatr i ich otoczeniem. 2. Nauki biologiczne, s. 11-15. Tatrzański Park Narodowy, Zakopane.

MireK Z., Nikel A. \& WiLK Ł. 2015. Coronilla vaginalis - a species new for the flora of Poland. - Acta Societatis Botanicorum Poloniae 84(1): 133-138.

Mirek Z, Piękoś-Mirkowa H. \& Stachurska-Swakoń A. 2008. Turzyca czarna Carex parviflora Host. - W: Z. MireK \& H. PięKoś-Mirkowa (red.), Czerwona księga Karpat polskich. Rośliny naczyniowe, s. 518-519. Instytut Botaniki im. W. Szafera Polskiej Akademii Nauk, Kraków.

Mirek Z., Pię́oś-Mirkowa H. \& Czerny M. 2013. Operat ochrony roślin i grzybów (rośliny naczyniowe). s. 136. Mskr. do projektu Planu Ochrony TPN, KRAMEKO sp. z o. o., Kraków.

Mirek Z., Pięroś-Mirkowa H., ZająC A. \& ZająC M. 2002. Flowering plants and pteridophytes of Poland - a checklist. - W: Z. MireK (red.), Biodiversity of Poland. 1, s. 442. W. Szafer Institute of Botany, Polish Academy of Sciences, Kraków.

Mirek Z., Bregin M., Nikiel A., PięKoś-Mirkowa H. \& Wilk Ł. 2012. Uzupełnienia do flory Tatrzańskiego Parku Narodowego i jego otuliny. - Fragmenta Floristica et Geobotanica Polonica 19(2): $570-573$.

Mráz P., Barabas D., Lengyelová L., Turis P., Schmotzer A., Janišová M. \& Ronikier M. 2016. Vascular plant endemism in the Western Carpathians: spatial patterns, environmental correlates and taxon traits. - Biological Journal of the Linnean Society 119(3): 630-648.

MYCZKOWSKI S. \& LESIŃSKI J. 1974. Rozsiedlenie rodzimych gatunków drzew tatrzańskich. - W: S. MYCZKOwsKI (red.), Rodzime drzewa Tatr. Część 1. - Studia Ośrodka Dokumentacji Fizjograficznej PAN 3: $13-70$.

PawŁowski B. 1925. Zapiski florystyczne z Tatr. II. - Acta Societatis Botanicorum Poloniae 3: 76-96.

PawŁowski B. 1956. Flora Tatr. 1. s. 672. Państwowe Wydawnictwo Naukowe, Warszawa.

Pawłowski B. \& STeCKi K. 1927. Zespoły roślin w Tatrach. Cz. IV. Zespoły roślin w dolinie Miętusiej i na głównym masywie Czerwonych Wierchów. - Rozprawy Wydziału Matematyczno-Przyrodniczego Akademji Umiejętności B: 79-121, 141-144.

PawŁowski B., SokoŁowski M. \& Wallisch K. 1928. Zespoły roślin w Tatrach. Cz. VII. Zespoły roślinne i flora doliny Morskiego Oka. - Rozprawy Wydziału Matematyczno-Przyrodniczego Akademji Umiejętności 6 A/B: 171-311.

Pį̨Kó́-Mirkowa H. 1982. Rzadkie taksony roślin naczyniowych na terenie Tatrzańskiego Parku Narodowego - ich zagrożenie ze strony turystyki oraz problem ochrony. - Studia Naturae, Seria A 33: 79-132.

Pięroś-Mirkowa H., Mirek Z. \& MiechówKa A. 1996. Materiały do flory ekologicznej Tatrzańskiego Parku Narodowego. Część I. - Fragmenta Floristica et Geobotanica Series Polonica 3: 77-84. 
RADWAŃSKA-PARYSKa Z. 1950. Tatrzańskie notatki florystyczne. - Acta Societatis Botanicorum Poloniae 20(2): 557-576.

RADWAŃSKA-PARYSKA Z. 1975. Materiały do rozmieszczenia dendroflory Tatr i Podtatrza. - W: S. MYCZKOWsKi (red.), Rodzime drzewa Tatr. Część 2. - Studia Ośrodka Dokumentacji Fizjograficznej PAN 4:13-77.

RAdwańska-PARYska Z. 1991. Zielnik brata Cypriana z Czerwonego Klasztoru. - Polish Botanical Studies, Guidebook Series 5: 3-216.

RutKowski L. 2007. Klucz do oznaczania roślin naczyniowych Polski niżowej. s. 814. Wydawnictwo Naukowe PWN, Warszawa.

SAGorski E. \& SchneIder G. 1891. Flora der Centralkarpathen. s. 591. E. Kummer Verlag, Leipzig.

SZAFER W., PAwŁowski B. \& KulCZYŃSKI S. 1923. Die Pflanzenassoziationen des Tatra - Gebirges. I Teil: Die Pflanzenassoziationen des Chochołowska Tales. - Bulletin International de l'Academie Polonaise des Sciences et des Lettres, Classe des Sciences Mathématiques et Naturelles, Serie B: Sciences Naturelles 1923, Supplement 3: 1-66.

Szwagrzyk J., Bodziarczyk J., Pielech R., ZięBa A. \& Zwijacz-Kozica T. 2019. Wpływ wiatrowałów i gradacji kornika drukarza oraz zabiegów ochronnych na szatę roślinną borów świerkowych w Tatrzańskim Parku Narodowym. - Parki Narodowe i Rezerwaty Przyrody 38(3-4): 57-68.

Šoltésová A., Dúbravcová Z., Piękoś-Mirkowa H., Mirek Z. \& Paclová L. 2010. Cievnaté rastliny. - W: A. Koutná \& B. Chovancová (red.), Tatry - príroda, s. 365-391. Baset, Praha.

Wróbel S. \& FiguRA T. 2018. Pajęcznica gałęzista Anthericum ramosum - nowy gatunek we florze Tatrzańskiego Parku Narodowego. - Chrońmy Przyrodę Ojczystą 75(2): 146-148.

Wróbel A. \& WRÓBEL S. 2018. Nowe stanowisko zimoziołu północnego Linnaea borealis w Tatrzańskim Parku Narodowym. - Chrońmy Przyrodę Ojczystą 74(1): 74-76.

ZAJĄC A. \& ZAJĄC M. (red.). 2001. Atlas rozmieszczenia roślin naczyniowych w Polsce. s. xii + 716. Pracownia Chorologii Komputerowej Instytutu Botaniki Uniwersytetu Jagiellońskiego, Kraków.

Zalewska-Gatosz J. 2008. Rodzaj Potamogeton L. w Polsce - taksonomia i rozmieszczenie. s. 218. Institute of Botany of the Jagiellonian University, Kraków.

ZIĘBA A. 2014. Nowe stanowisko mącznicy lekarskiej Arctostaphylos uva-ursi w Tatrach polskich. - Chrońmy Przyrodę Ojczystą 70(4): 362-366.

ZięBA A. 2018. Nowe stanowisko rzadkich gatunków alpejskich roślin w Tatrzańskim Parku Narodowym. - Fragmenta Floristica et Geobotanica Polonica 25(2): 169-182.

ZięBA A. \& BARAn J. 2017. Nowe stanowiska storczyków (Orchidaceae) w Tatrzańskim Parku Narodowym. - Chrońmy Przyrodę Ojczystą 73(6): 484-488.

ZwiJacz-Kozica T. 1997. Przyczynki do flory Tatrzańskiego Parku Narodowego. - Parki Narodowe i Rezerwaty Przyrody 16(4): 87-92.

ZwiJacZ-Kozica M. \& ZwIJACZ-Kozica T. 2018. Największy kwiat pod Tatrami. - Tatry TPN 65(3): 58.

ZwolińsKa Z. 1957. Notatki florystyczne z Tatr i Podhala. - Fragmenta Floristica et Geobotanica 3(2): $19-22$.

\section{SUMMARY}

The Tatras are the highest mountains in central Eastern Europe, divided between Poland and Slovakia. They are a biodiversity hotspot, with 1400 vascular plant species. Botanical research in these mountains dates back to the 18th century, but the most significant progress in recognition of the flora of the Tatras occurred in the late 19th and the 20th centuries. Though many detailed botanical studies have been carried 
out in the Tatra Mts, every year new floristic discoveries are reported. This paper presents new localities of rare and threatened species of Tatra National Park (TNP) in Poland.

The data were collected during several research projects carried out between 2010 and 2019. We present new TNP localities of rare and threatened species as assigned in the Polish Red Data Book of Plants (KaźMierczakowa et al. 2014), Red Data Book of the Polish Carpathians - Vascular Plants (MireK \& PięKoŚ-Mirkowa 2008) and Polish red list of pteridophytes and flowering plants (KAźMIERCZAKOWA et al. 2016), and report some new species for TNP. The locality descriptions include concise topographic and habitat characteristics, as well as basic information on population size and the date and author of the records. Precise coordinates are stored in the geodatabase of vascular plants of Tatra National Park.

We present 131 localities of 42 taxa (including 8 newly discovered for Tatra National Park). Research done in recent years has contributed important information about the biodiversity of the flora of the Polish Tatras. Here we describe new localities of rare and endangered species in Poland and Carpathians, such as Carex parviflora, C. pauciflora, Cotoneaster tomentosus, Draba carinthiaca, D. dubia, Epipogium aphyllum (Fig. 2), Saussurea pygmaea, Senecio aurantiacus and Woodsia alpina (Fig. 3), including Carpathian and Tatra endemic species (Campanula serrata, Cochlearia tatrae, Poa nobilis). Extensive field studies yielded distribution and ecological data for species classified as data-deficient (DD) the Red Books and Red List (Arctium nemorosum, Poa nobilis, Potamogeton berchtoldii). Data on the vertical ranges of species have also been significantly revised, upward by $500 \mathrm{~m}$ (from 1280 to $1770 \mathrm{~m}$ a.s.l.) in the case of Cypripedium calceolus (Fig. 1); $1770 \mathrm{~m}$ a.s.l is now the current maximum for that orchid in the Polish Carpathians. We also found 8 new species in the local flora. Most of the newly discovered species in TNP are plants typical for lower elevations and common in Polish lowlands. This may suggest a slow shift of lowland species towards higher elevations, due to climate change.

Wptynęto: 06.02.2020 r.; przyjęto do druku: 31.07.2020 r. 